\title{
Long-term damage from the Great Recession in OECD countries
}

\author{
Laurence Ball* \\ Department of Economics, Johns Hopkins University, Baltimore, MD, USA
}

\begin{abstract}
This paper estimates the long-term effects of the global recession of 2008-2009 on output in 23 countries. I measure these effects by comparing current estimates of potential output from the OECD and IMF to the path that potential was following in 2007, according to estimates at the time. The losses in potential output range from almost nothing in Australia and Switzerland to more than 30 percent in Greece, Hungary, and Ireland; the average loss, weighted by economy size, is 8.4 percent. Most countries have experienced strong hysteresis effects: shortfalls of actual output from pre-recession trends have reduced potential output almost one-for-one. In the hardest-hit economies, the current growth rate of potential is depressed, implying that the extent of lost potential is growing over time.
\end{abstract}

Keywords: Great Recession, hysteresis, potential output

JEL codes: $E 32, E 65, E 66$

\section{INTRODUCTION}

According to textbooks in macroeconomics, a fall in aggregate demand causes a recession in which output drops below potential output - the normal level of production given the economy's resources and technology. This effect is temporary, however. A recession is followed by a recovery period in which output returns to potential, and potential itself is not affected significantly by the recession.

This textbook theory has been called into question by, amongst others, Cerra/Saxena (2008), IMF (2009), and Reinhart/Rogoff (2009). These studies examine deep recessions around the world and find highly persistent effects on output. Haltmaier (2012) and Reifschneider et al. (2013) argue that these effects occur because a recession reduces an economy's potential output. Potential output falls because a recession reduces capital accumulation, leaves scars on workers who lose their jobs, and disrupts the economic activities that produce technological progress. Some economists use the term 'hysteresis' for these long-term effects of recessions (Blanchard/Summers 1986).

Experience since the global financial crisis and Great Recession of 2008-2009 has strengthened the evidence for long-term effects of recessions. Reinhart/Rogoff (2014) point out that output in many countries is still highly depressed in 2014, with authorities such as the IMF forecasting weak recoveries in the next 5 years. As Summers (2014) puts it: 'This financial crisis has confirmed the doctrine of hysteresis more strongly than anyone might have supposed.'

This paper uses OECD estimates of potential output in 23 countries to quantify the long-term damage from the Great Recession. For each country, I take the path that potential

* I am grateful for excellent research assistance from Daniel Garcia Molina and for suggestions from Daniel Leigh. 
output was following before the financial crisis, according to OECD estimates from December 2007, and extrapolate this path through 2015. I compare this pre-crisis trend to estimates of potential output in the most recent vintage of OECD data (May 2014), and interpret the differences as effects of the recession. To check robustness, I do a similar exercise using IMF estimates of potential output from October 2007 and from April 2014.

I find that the loss in potential output from the Great Recession varies greatly across countries, but is large in most cases. Based on current forecasts for 2015, the loss ranges from almost nothing in Switzerland and Australia to over 30 percent of potential output in Greece, Hungary, and Ireland. The average loss for the 23 countries, weighted by the size of their economies, is 8.4 percent.

The analysis also yields two related results. First, in most countries the loss of potential output is almost as large as the shortfall of actual output from its pre-crisis trend. This finding implies that hysteresis effects have been very strong during the Great Recession.

Second, in the countries hit hardest by the recession, the estimated growth rate of potential output is significantly lower today than it was before 2008. This growth slowdown means that the level of potential output is likely to fall even farther below its pre-crisis trend in the years to come.

\section{METHODOLOGY}

I examine 23 OECD countries that meet two criteria: (1) the population exceeds one million; and (2) the OECD published estimates of the country's potential output in its Economic Outlooks for both December 2007 and May 2014. The 23 countries include 20 that have belonged to the OECD since the 1960s or 1970s, plus three that joined in the 1990s: the Czech Republic, Hungary, and Poland. ${ }^{1}$

Beffy et al. (2006) describe the OECD's method for estimating potential output, which is based on a production function. OECD economists estimate the long-run trends in labor input, the capital stock, and total factor productivity. The trend in labor input is determined by trends in the labor force, unemployment, and hours of work. The various trends are plugged into the production function to determine the path of potential output.

I take annual series for output, $\mathrm{Y}$, and potential output, $\mathrm{Y}^{*}$, from the OECD Economic Outlook for May 2014. These series include forecasts of $Y$ and $Y^{*}$ through 2015. To assess the damage from the Great Recession, I also need estimates of the levels that potential output would have attained if not for the recession. To produce these estimates, which I denote by $\mathrm{Y}^{* *}$, I examine the paths for potential output that countries were following as of 2007 .

Specifically, the Economic Outlook for December 2007 includes series for potential output through 2009. I take these pre-crisis data as estimates of $\mathrm{Y}^{* *}$, and extend the series beyond 2009 with log-linear extrapolation. Letting $y^{* *}$ denote the $\log$ of $\mathrm{Y}^{* *}$, I compute the average annual change in $y^{* *}$ from 2000 to 2009 , and assume the change in $y^{* *}$ is constant at that level from 2009 to $2015 .^{2}$

Figure 1 illustrates this procedure for the United States. The figure shows the logs of $Y$, $\mathrm{Y}^{*}$, and $\mathrm{Y}^{* *}$, with logs again denoted by lower-case y's. In the December 2007 data, the

1. I exclude one country that meets the two criteria: Norway. The OECD series for Norway's potential output is volatile, making it difficult to project the pre-crisis path of potential into the future. This problem may reflect the large share of oil in Norway's output.

2. The base years for the output series differ across countries, and they differ between the December 2007 and May 2014 Outlooks. For each country, I make the two vintages of data consistent by multiplying the December 2007 series for output and potential output by a ratio: (output in 2000 in the May 2014 data)/(output in 2000 in the December 2007 data). 


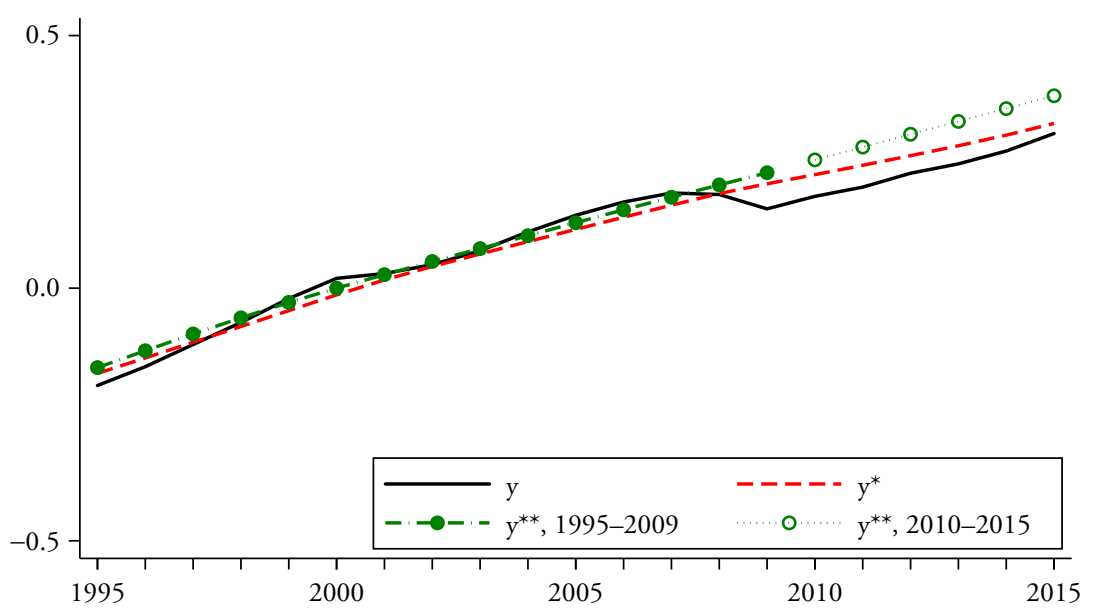

Note: $\mathrm{y}^{* *}$ is normalized to zero in 2000 .

Sources: y and $y^{*}$ : OECD Economic Outlook May 2014. y* $^{* *}$ 1995-2009: OECD Economic Outlook December 2007. $y^{* *}, 2010-2015$ : extrapolated from $y^{* *}, 2000-2009$.

Figure 1 Long-term damage in the United States

change in $\mathrm{y}^{* *}$ is almost constant from 2000 to 2009, which implies that the path of $\mathrm{y}^{* *}$ in the figure is close to a straight line. In extrapolating the data, I essentially extend the straight line beyond 2009.

In 2013, the difference between $y^{* *}$ and $y^{*}$ in the United States was 0.048 , and the difference between $\mathrm{y}^{*}$ and $\mathrm{y}$ was 0.036 . The difference between the levels of $\mathrm{Y}^{* *}$ and $\mathrm{Y}^{*}-$ the loss of potential output relative to its pre-crisis path - was 4.7 percent of $Y^{* *}$. The difference between $\mathrm{Y}^{*}$ and $\mathrm{Y}$ - the current gap between potential and actual output - was 3.4 percent of $\mathrm{Y}^{* *}$. According to current OECD forecasts, the loss of potential output will grow to 5.3 percent in 2015 while the output gap will fall to 1.9 percent. (I compute exact percentage losses because, for some countries considered below, the losses are large enough to make approximation by log differences inaccurate.)

As a robustness check, I also estimate losses in potential output with data from the IMF's World Economic Outlook, using data from April 2014 on actual and potential output and data from October 2007 on the pre-crisis path of potential. The series in the 2007 WEO end in 2008, so I extrapolate $y^{* *}$ over 2009-2015 based on its path over 2000-2008. The WEO data are available for 17 of the 23 countries in the OECD sample. For the United States, the loss of potential output is 7.7 percent in 2015, somewhat higher than the estimate based on OECD data.

For the United States, several other studies estimate the loss of potential output since the onset of the financial crisis. Fernald (2012) estimates a loss of potential of 5 percent in 2011; Reifschneider et al. (2013) estimate 6 percent in the first quarter of 2013; and CBO (2014) predicts a loss of 7.3 percent in 2017. My estimates of lost potential in the US are about the same magnitude as previous estimates. ${ }^{3}$

3. The CBO says it has reduced its forecast of potential output in 2017 based on reassessments of long-run trends in employment and productivity, and that most of this revision is not a result of the Great Recession. Ball et al. (2014) dispute the CBO's interpretation of its forecast revision. 


\section{RESULTS}

Here I estimate the loss of potential output in each of the 23 countries in my sample. I also compute the average loss across countries weighted by the size of their economies, as measured by $\mathrm{Y}^{* *}$ in $2015 .{ }^{4}$

For each country, Figure 2 shows the paths of $y, y^{*}$, and $y^{* *}$. In most cases, as in the United States, the path of $\mathrm{y}^{* *}$ is close to a straight line. Table 1 gives summary statistics, focusing on losses in 2013 and forecast losses in 2015. Several points emerge from the results.

\subsection{Lost potential}

The damage from the Great Recession varies greatly across countries. For 2015, the losses of potential output range from approximately zero in Switzerland and less than 2 percent in Australia to more than 30 percent in Greece, Hungary, and Ireland. The US loss of 5.3 percent is lower than most. Figure 3 captures this cross-country variation in a bar graph.

For the entire sample, the weighted average of the loss in potential output is 7.2 percent in 2013 and rises to 8.4 percent in 2015. Measured in 2015 US dollars, the 8.4 percent loss for the 23 countries adds up to $\$ 4.3$ trillion.

The IMF data produce estimated losses that are similar to those from the OECD data. Figure 4 illustrates this point by comparing the 2015 losses of potential based on the two sources, for the 17 countries covered by both. The majority of countries fall just above the 45 degree line, indicating slightly larger losses in the IMF data.
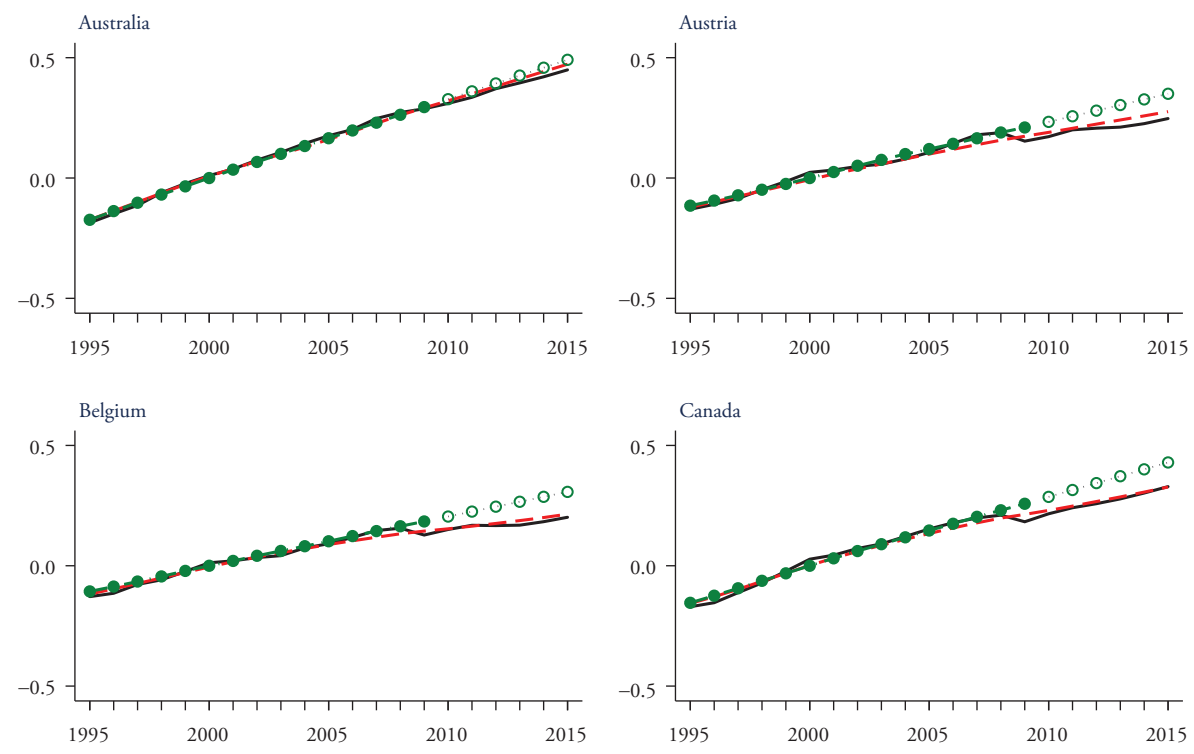

Figure 2 Long-term damage in 23 countries

4. Each country's weight is proportional to the product of (2015 nominal GDP in dollars) and $\left(\mathrm{Y}^{* *} / \mathrm{Y}\right)$. Nominal GDP in dollars is taken from the April $2014 \mathrm{WEO}$, because the OECD does not report this variable. 

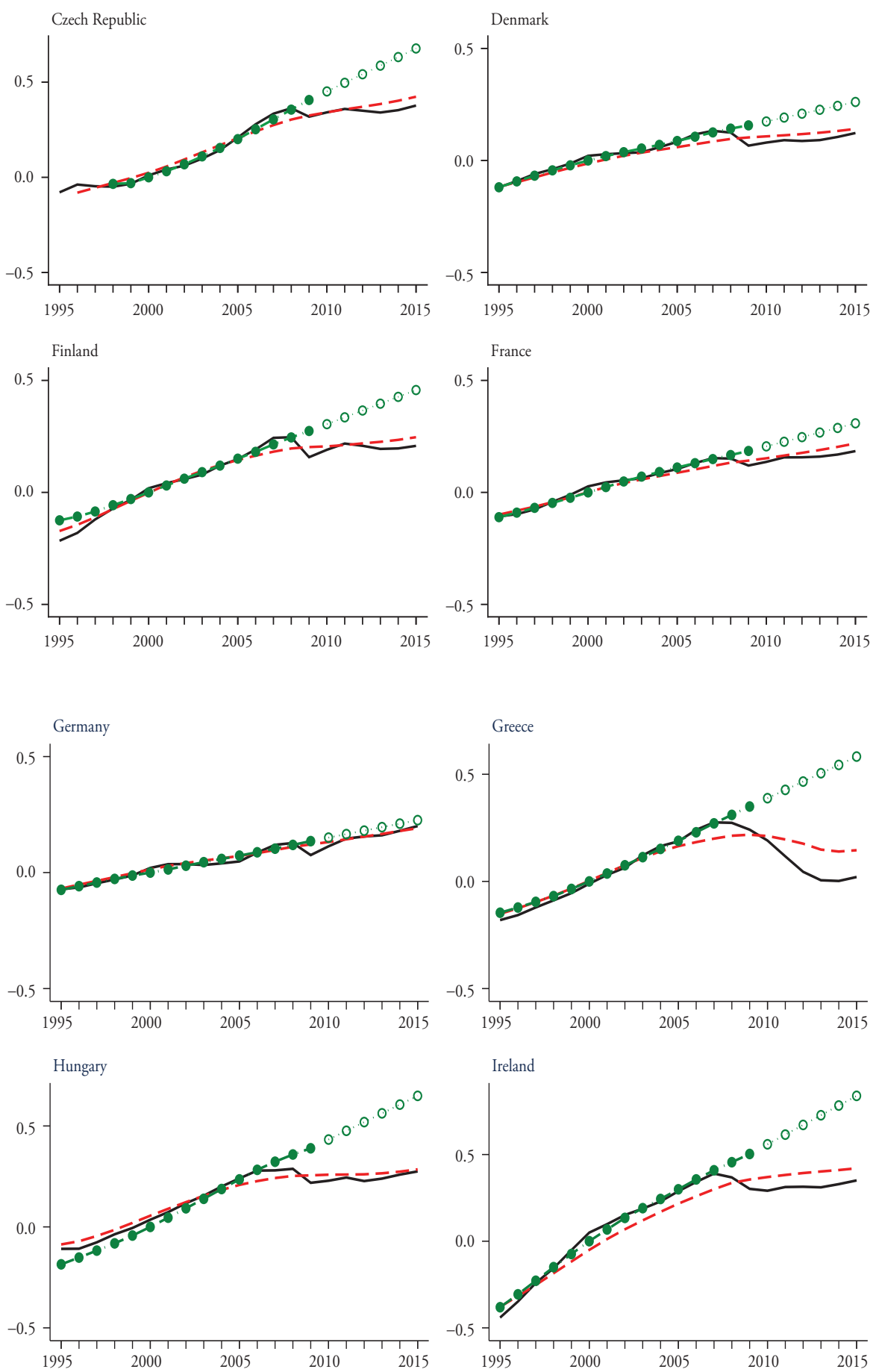

Figure 2 (Continued) 
154 European Journal of Economics and Economic Policies: Intervention, Vol. 11 No. 2
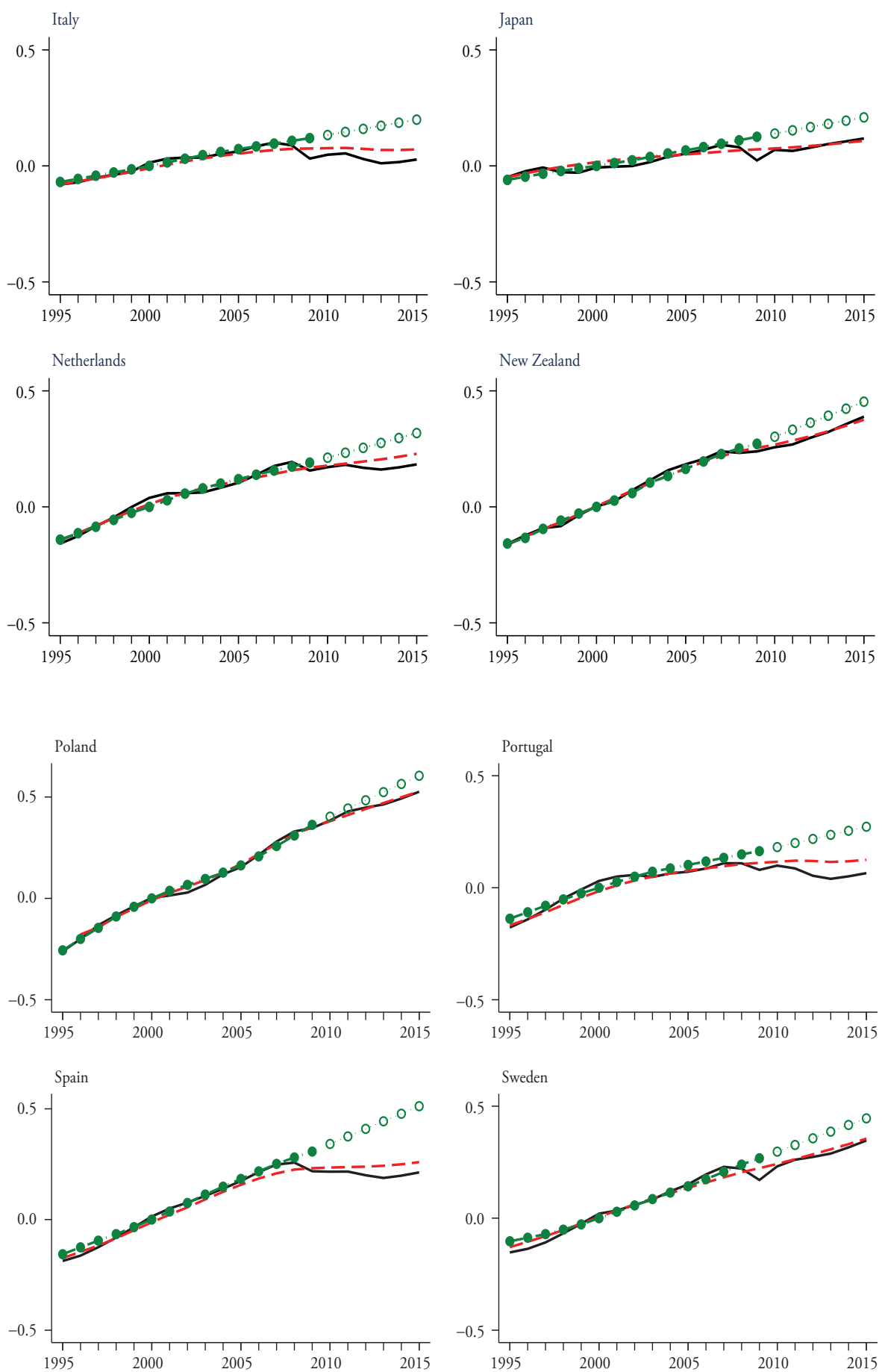

Figure 2 (Continued) 

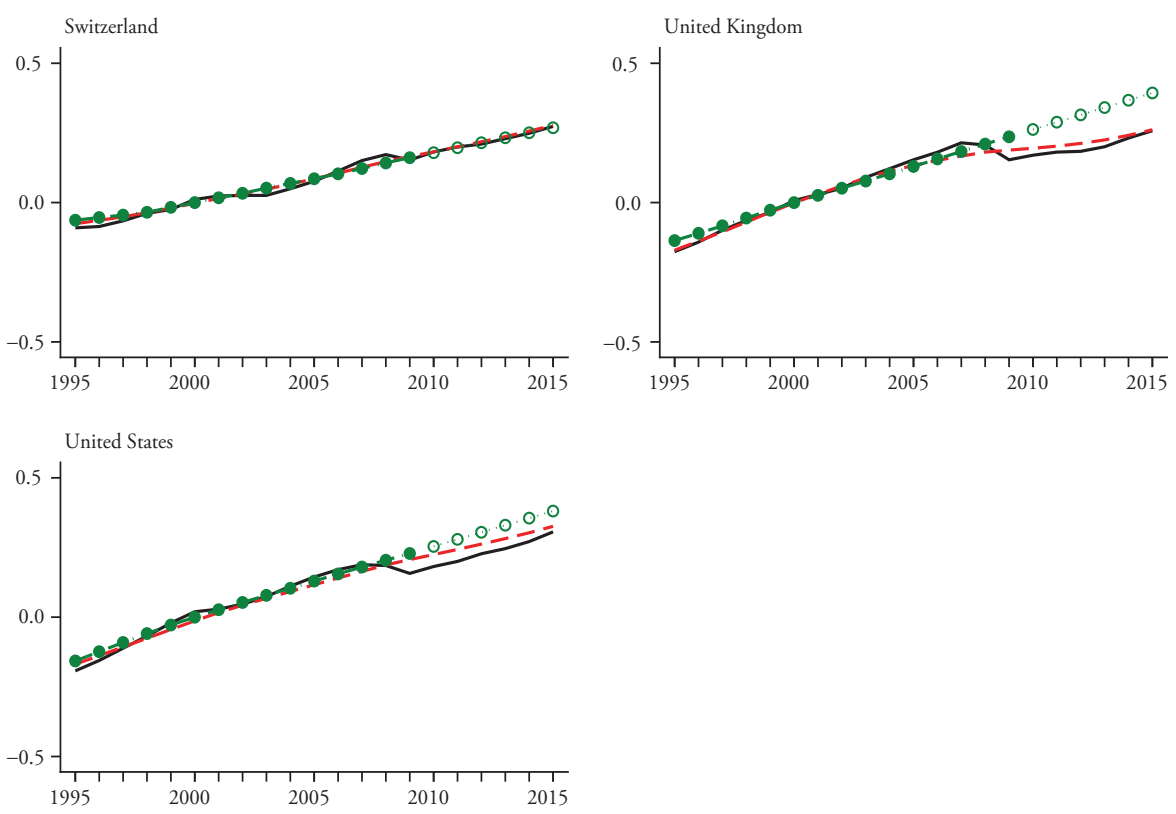

Figure 2 (Continued)

\subsection{Actual vs potential output}

In most countries, the deviations of potential output from its pre-crisis path are smaller than the deviations of actual output from the same path, but only by modest amounts. We can see this in Figure 2: for most countries, the line for $\mathrm{y}^{*}$ is not far above the line for $y$. Figure 5 makes this point by plotting each country's percentage deviation of $Y^{*}$ from $\mathrm{Y}^{* *}$ against its deviation of $\mathrm{Y}$ from $\mathrm{Y}^{* *}$, both in 2015. In this graph, many countries are close to the 45-degree line.

According to these results, hysteresis has been remarkably strong during the Great Recession. In many countries, as the recession has pushed actual output below its pre-crisis trend, the effect on estimated potential output has been almost one-for-one.

Averaging across the 23 countries, actual output, $\mathrm{Y}$, is 9.74 percent below $\mathrm{Y}^{* *}$ in 2013. This deviation from the pre-crisis trend is the sum of a 7.18 percent loss of potential output and a 2.56 percent gap between the current levels of potential and actual output (both measured as percentages of $\left.\mathrm{Y}^{* *}\right)$. In 2015, the deviation of $\mathrm{Y}$ from $\mathrm{Y}^{* *}$ is 9.87 percent, split into an 8.38 percent loss of potential and a 1.49 percent gap between potential and actual output.

\subsection{Prospects for the future}

In some countries, potential output has fallen significantly below its pre-crisis path, but the current growth rate of potential is not far from its old normal. In the United States, for example, the May 2014 OECD Outlook predicts that potential output will grow at an average rate of 2.23 percent over 2014-2015; this growth rate is only modestly lower than 


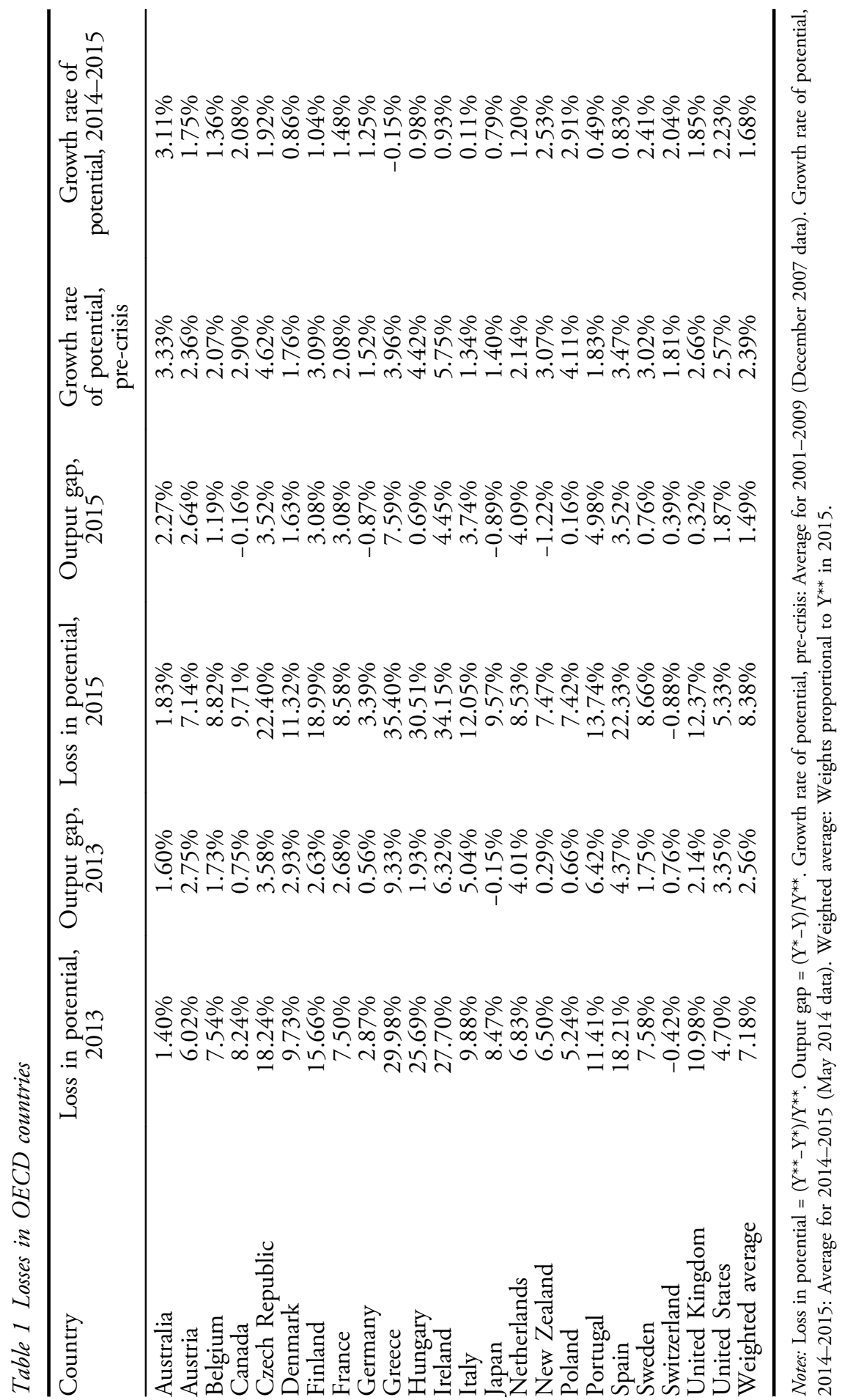




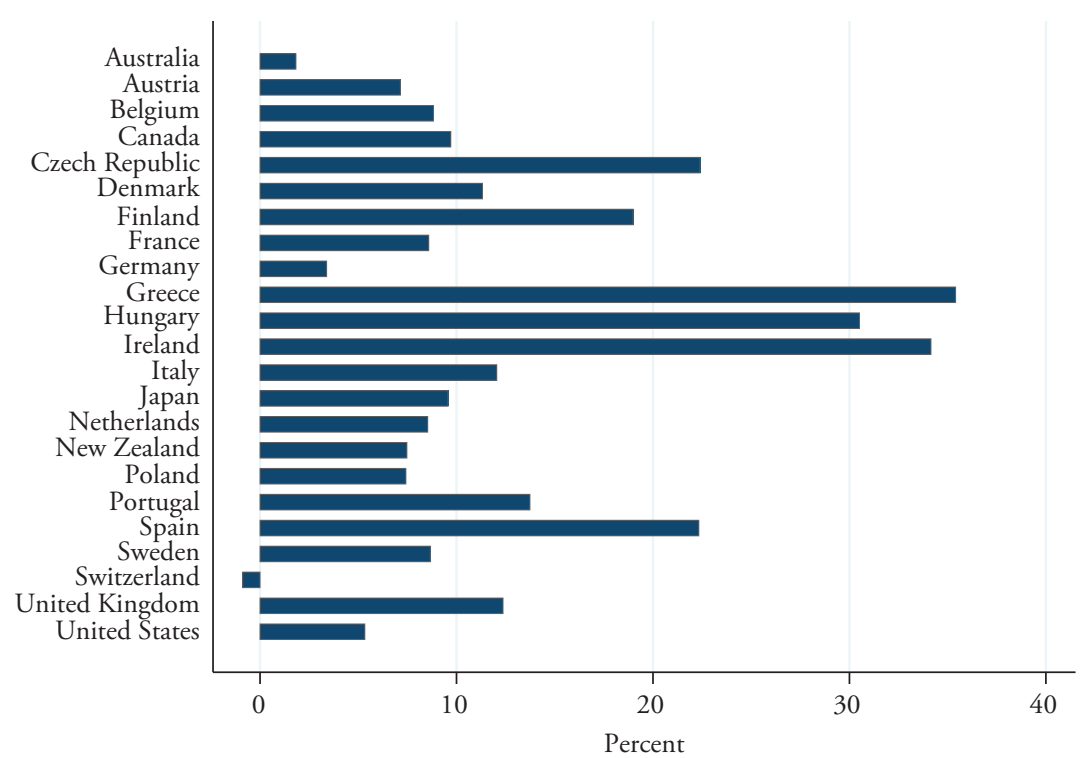

Figure 3 Loss of potential output, 2013

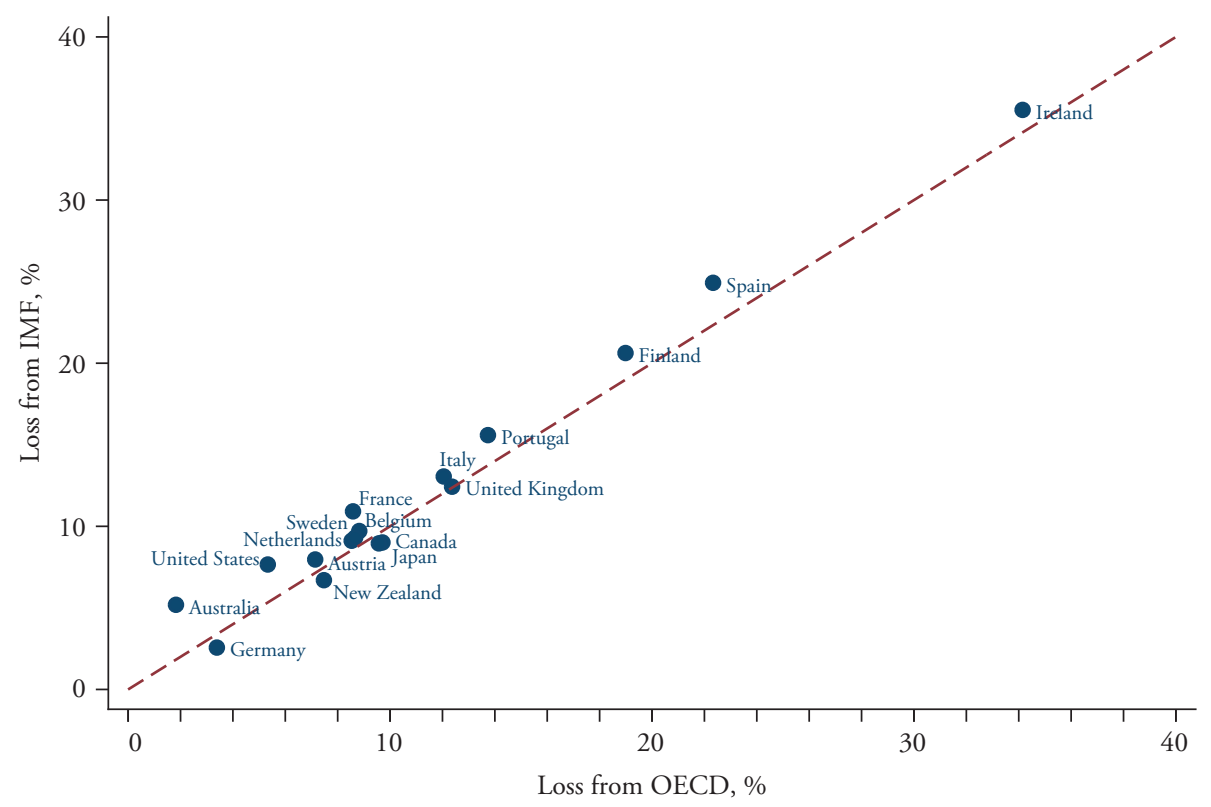

Figure 4 Loss of potential, 2015, from IMF and OECD

the 2.57 percent average reported for 2001-2009 in the December 2007 Outlook. This similarity means that the current paths of $\mathrm{y}^{*}$ and $\mathrm{y}^{* *}$ are roughly parallel, with a stable gap between the two variables. 


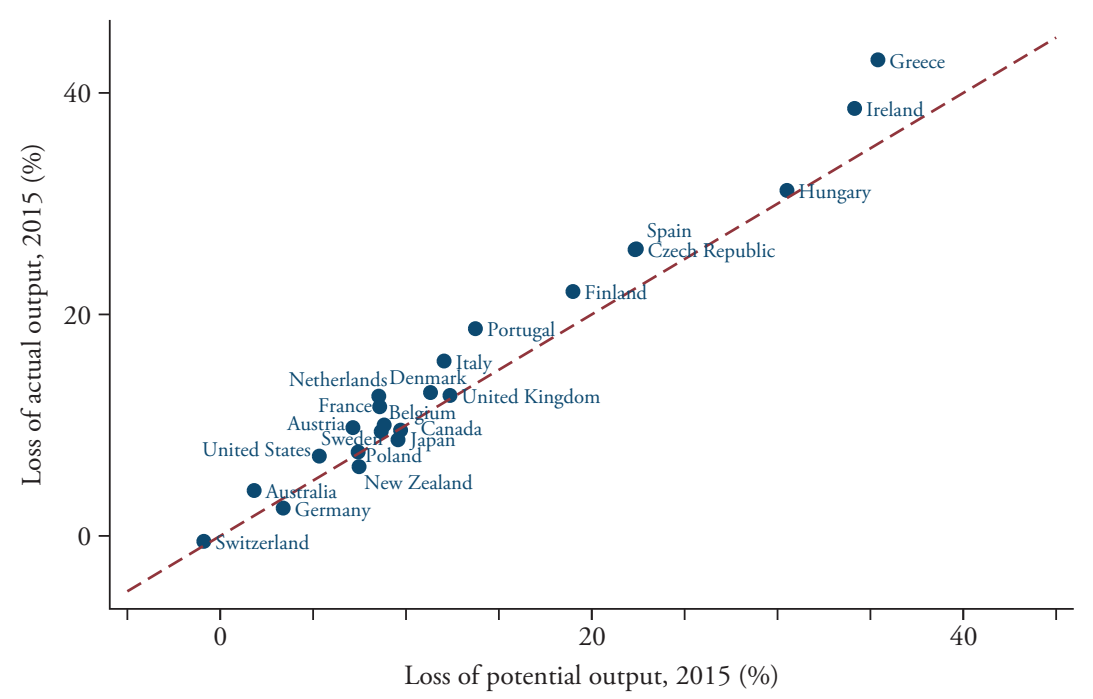

Note: Loss of actual output $=($ Loss of potential output $)+($ Gap between potential and actual output $)$.

Figure 5 Actual vs potential output, 2015

In other countries, however, the current growth rates of potential output are much lower than past rates. In Ireland, the May 2014 Outlook predicts that potential will grow at an average rate of only 0.9 percent over 2014-2015, compared to a 5.8 percent growth rate in the pre-crisis data for 2001-2009. In Greece, the predicted growth rate is -0.2 percent for 2014-2015, compared to 4.0 percent in the pre-crisis data. In these countries, if potential growth rates remain at current depressed levels, then the losses of potential output relative to pre-crisis trends will grow rapidly over time.

As these examples suggest, the countries with the largest current losses of potential output also have poor prospects going forward. To make this point, Figure 6 plots each country's percentage loss of potential output in 2015 against its current growth depression: the growth rate of potential over 2001-2009 in the December 2007 data minus the growth rate over 2014-2015 in the May 2014 data. The correlation in Figure 6 implies that - absent sharp accelerations in potential growth - the countries damaged most by the Great Recession will do worse and worse over time relative to other countries as well as to their own pre-crisis trajectories.

Averaged across countries, the pre-crisis growth rate of potential over 2001-2009 is 2.4 percent, and the predicted growth rate over 2014-2015 is 1.7 percent. The difference between these two rates, 0.7 percent, is the average growth depression. If potential output continues to grow at the rates predicted for 2014-2015, the level of potential in the average country will fall below its pre-crisis path by an additional 0.7 percentage points per year.

\section{DISCUSSION}

The global financial crisis of 2008-2009 triggered national recessions of varying severity. The hardest-hit economies include those in the periphery of the euro area, which experienced severe banking and debt crises. At the other extreme, Australia was almost unscathed because of factors including fiscal stimulus and strong exports to Asia (OECD 2010). 


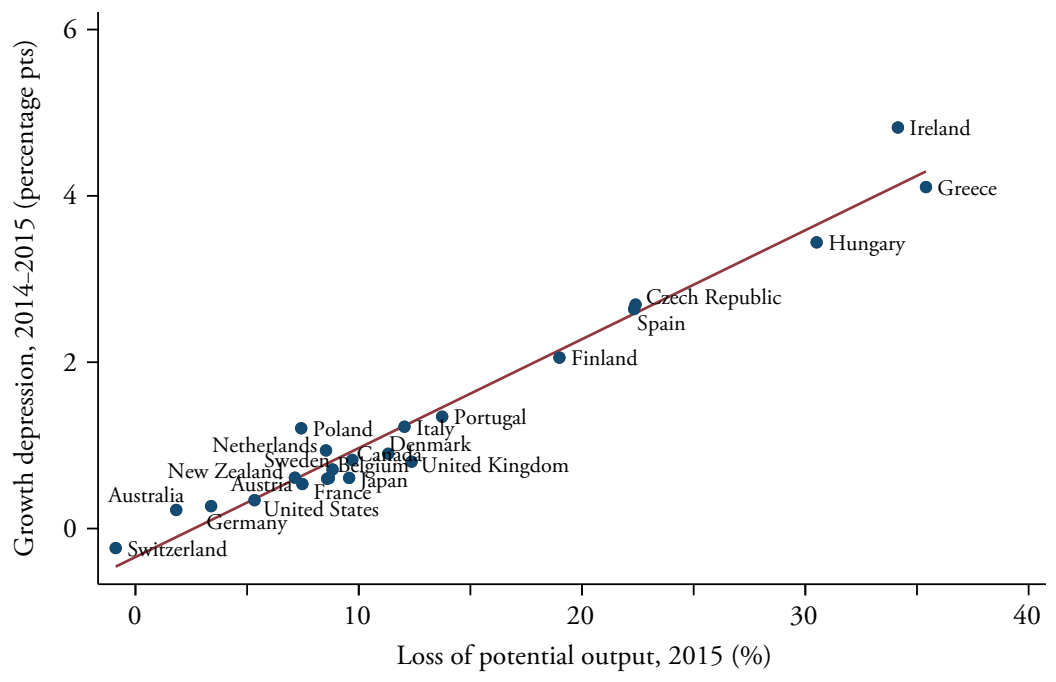

Note: Growth depression $=($ Average growth rate of potential over 2001-2009, from Dec 2007 data) - (Average growth rate of potential over 2014-2015, from May 2014 data).

Figure 6 Lost potential vs current growth depression

This paper finds that the recent recessions have had dire effects on economies' productive capacity, as measured by OECD and IMF estimates of potential output. In most countries, the fall in potential relative to its pre-crisis trend has been almost as large as the fall in actual output. Consequently, the countries with the deepest recessions have also experienced the greatest long-term damage.

If we aggregate the 23 countries in my sample, the loss of potential output relative to its pre-crisis path is 8.4 percent in 2015. To appreciate the size of this loss, note that Germany accounts for 8.2 percent of the aggregate economy. The total damage from the Great Recession is slightly larger than the loss of Germany's entire economy from global production.

Through what mechanisms do recessions reduce potential output? This question is addressed for past financial crises by IMF (2009) and for the recent US experience by Reifschneider et al. (2013), Hall (2014), and Yang (2014). While the results vary, it appears that recessions sharply reduce capital accumulation; have long-term effects on employment (largely through lower labor force participation); and may slow the growth of total factor productivity. This last effect is poorly understood; one possible factor is a decrease in the formation of businesses with new technologies (Fort et al. 2013; Reifschneider et al. 2013). A better understanding of hysteresis mechanisms is a high priority for research.

Another pressing question is whether hysteresis effects are reversible. Some researchers suggest that these effects are asymmetric; for example, Reifschneider et al. (2013) assume that a recession causes a persistent fall in labor force participation and rise in unemployment, but strong output growth does not have the opposite effects. If this view is correct, then macroeconomic policymakers cannot repair the long-term damage from the Great Recession.

On the other hand, provided policymakers can somehow create a strong economic expansion, hysteresis might work in reverse. Procyclical investment could increase the capital stock; plentiful job opportunities could increase workers' attachment to the labor force; and so on. My past research (Ball 1999; 2009) suggests that hysteresis in the unemployment rate works 
in reverse; in the United Kingdom, for example, economic booms in the late 1980s and 1990s reduced the natural rate of unemployment. Today, a strong expansion could push employment and potential output back toward their pre-crisis paths. Failing that, the expansion might at least reverse declines in the growth rate of potential, so the damage from the Great Recession does not continue to grow.

\section{REFERENCES}

Ball, Laurence (1999): Aggregate demand and long-run unemployment, in: Brookings Papers on Economic Activity, 1999(2), 189-236.

Ball, Laurence (2009): Hysteresis: old and new evidence, in: Fuhrer, Jeff, Kodrzycki, Yolanda K., Little, Jane Sneddon, Olivei, Giovanni P. (eds), Understanding Inflation and the Implications for Monetary Policy: A Phillips Curve Retrospective, Cambridge, MA: MIT Press, 361-382.

Ball, Laurence, DeLong, Brad, Summers, Larry (2014): Fiscal policy and full employment, Full Employment Project, Center for Budget and Policy Priorities, April.

Beffy, Pierre-Olivier, Ollivaud, Patrice, Richardson, Pete, Sedillot, Franck (2006): New OECD methods for supply-side and medium-term assessments: a capital services approach, OECD Economic Department Working Paper \#482, July.

Blanchard, Olivier J., Summers, Lawrence H. (1986): Hysteresis and the European unemployment problem, in: NBER Macroeconomics Annual, Cambridge, MA: MIT Press, 15-90.

CBO (Congressional Budget Office) (2014): Revisions to CBO's projection of potential output since 2007, Report, February.

Cerra, Valerie, Saxena, Sweta Chaman (2008): Growth dynamics: the myth of economic recovery, in: American Economic Review, 98(1), 439-457.

Fernald, John (2012): Productivity and potential output before, during, and after the great recession, Federal Reserve Bank of San Francisco Working Paper \#2012-18, September.

Fort, Teresa C., Haltiwanger, John, Jarmin, Ron S., Miranda, Javier (2013): How firms respond to business cycles: the role of firm age and firm size, NBER Working Paper \#19134, June.

Hall, Robert E. (2014): Quantifying the lasting harm to the U.S. economy from the financial crisis, in: NBER Macroeconomics Annual, Cambridge, MA: MIT Press (forthcoming).

Haltmaier, Jane (2012): Do recessions affect potential output? International Finance Discussion Paper \#1066, Federal Reserve Board, December.

IMF (International Monetary Fund) (2009): What's the damage? Medium-term output dynamics after financial crises, in: World Economic Outlook, Washington, DC: International Monetary Fund, 121-150.

OECD (Organisation for Economic Co-operation and Development) (2010): Economic Survey of Australia, Paris: OECD.

Reifschneider, Dave, Wascher, William L., Wilcox, David (2013): Aggregate supply in the United States: recent developments and implications for the conduct of monetary policy, 14th Jacques Polak Annual Research Conference, Washington, DC, November.

Reinhart, Carmen M., Rogoff, Kenneth S. (2009): The aftermath of financial crises, in: American Economic Review, 99(2), 466-472.

Reinhart, Carmen M., Rogoff, Kenneth S. (2014): Recovery from financial crises: evidence from 100 episodes, in: American Economic Review, 104(5), 50-55.

Summers, Lawrence H. (2014): Speech at the Center for Budget and Policy Priorities Event on Full Employment, Washington, DC, 2 April.

Yang, David (2014): unpublished analysis at Harvard University. 